\title{
Translation of Substitution Units from English into Bahdini Kurdish
}

\author{
Najim A. Siddiq and Ahmad R. Khalel \\ Department of English, College of Basic Education, \\ University of Duhok, Duhok, Iraq
}

\begin{abstract}
Substitution is a phenomenon that exists in almost all languages. It is a technique usually used in linguistics to refer to the process of permutation of one feature of the previous expression. Each language has its specific substitutional units which are used to avoid repetition and to make the text more cohesive. Translating substitutive units from English into Bahdini Kurdish pose some problems for translators if they do not have a good knowledge of the substitutional units. This study, therefore, aims at studying substitutions units in both English and Bahdini Kurdish. It also attempts to show the similarities and differences between the two languages and to examine some problems that stem from translating substitutive unit from English into Bahdini Kurdish. The study hypothesizes that context, in which substitutive units occur, plays an important role in governing these units.
\end{abstract}

KEY WORDS: Substitution, Translation, Equivalent, Rendering, Kurdish, Language.

\section{THE CONCEPT OF SUBSTITUTION}

Substitution is a phenomenon that can be found in all languages, but the ways of substitution may vary from one language to another as it may be used in one language more frequently than another. Substitution can occur at different levels. It may occur at the level of the word, the phrase, the clause, or even the text. The main function of substitution is to avoid repetition, to shorten the message, and to make the message clearer to the reader. Another function of substitution is to link the sentences without disarranging the information. According to Klein (1967. p. 1535), the origin of word "substitution" comes from Latin verb "substitute" which means to put something or somebody in place of another. The term substitution refers to the words we use (e.g., so, one, do, did, and does) as signals indicating that something has been left out and identifying what kind of information it is. (Parrot, 2000. p. 320). The clearest and simplest instances of substitution are the words "yes" and "no," both of which can stand

Academic Journal of Nawroz University (AJNU)

Volume 6, No 3(2017), 7 pages

Received 08 September 2016; Accepted 08 October 2016

Regular research paper: Published 18 July 2017

Corresponding author's e-mail: najim.a@uod.ac

Copyright @2017 Najim Abdullah Siddiq, Ahmad R. Khalel. This is an open-access article distributed under the Creative Commons Attribution License. for long sentences or sequences of sentences (ibid) tion of the text.

\section{WHAT IS SUBSTITUTION}

Substitution, in general, is a process of putting one unit in place of another Thi (2011. p. 10). Something is missing, but instead of just leaving it out, we substitute it with another word, usually "so," "one(s)," "do (es)," "did" Querol (2012. p. 112). The prominent American linguist Bloomfield (1933) states that substitution is one of three great classes of grammatical forms of a language in addition to "sentence-type" and "constructiontypes" (247). He defines substitution as "a linguistic form of a language that replaces one of the classes of the linguistic forms under certain conventional circumstances. Substitution as a grammatical device is also defined by the linguist Whitehall (1956. p. 97) who claims that two grammatical devices are existents. The first one is known as "selection while the second one is known as substitution." He mentions that there are two types of substitutes. The first one is "Parallel one" and it is sometimes used as substitution. The second type of substitutes is "systematic substitute." This kind of substitution is regarded as a special class of substitutional words which coordinate with full words and empty words. Conlin (1961 p. 211), on his part, states

Original article | doi: 10.25007/ajnu.v6n3a72 
that substitution is a grammatical device and it is of two forms. The first one is "purely structural substitution" which gives flexibility in the process of communication, while the second form helps people avoid repetition by using short units. Quirk (1968. p. 11) views substitution as "a key stone" in grammatical analysis, and the term of substitution has got "a pseudoscientific status" due to its formal features. For Haliday and Hasan (1976. p. 88), substitution can be defined as "a replacement of one item by another one." This linguistic relation is a lexicogrammatical device and contributes to the continuity of the text or discourse. Substitution is a type of cohesion that maintains relations on the lexico-grammatical level of a sentence or a sentence in a text. It is performed by using a substitute that is a sort of counter employed in place of the repetition of a particular item. The substitute has the same structural function as that for which it substitutes. Yeh (2004. p. 131). To conclude, as a process within the text, substitution functions as the replacement of one item by another. It is a relation in the wording rather than in the meaning, i.e., substitution is a relation between linguistic items. In terms of the linguistic substitution, it is a relation on the lexico-grammatical level, the level of grammar and vocabulary, or linguistic "form." Substitution is a verbal relation which is essentially confined to the text.

\section{THE MODEL ADOPTED}

According to Newmark (1982. p. 7), there are two types of translations: Semantic translation and communicative translation. The model adopted in this study is communicative translation as it reproduces the same effect on the target language reader as that of the source language text reader. In communicative translation, the translator has the right to remove all types of obstacles, to avoid repetition of all unnecessary items and to add or remove anything he finds necessary for better rendering.

\section{PROCEDURES AND DATA COLLECTION}

In this study, 13 texts have been chosen to be translated from English into Kurdish by five subjects. The subjects were $4^{\text {th }}$ students at the Department of English, College of Basic Education, University of Duhok.

\section{TYPES OF SUBSTITUTION IN ENGLISH}

Since substitution is a grammatical relation, a relation in the wording rather than in the meaning, the different types of substitution are defined grammatically rather than semantically. In English, the substitute may function as a noun, as a verb, as a clause. To these correspondence, there are three types of substitution Haliday and Hasan (1976. p. 90). They are as follows:

\subsection{Nominal Substitution}

Nominal substitution means the replacement of a pronoun or noun or a noun phrase by a nominal substitute. Nominal substitution functions either as the head of the nominal group or as to presuppose an entire nominal group.

\subsubsection{Personal pronouns}

Not all personal pronouns operate as substitutes. Only the third person pronoun can be regarded as substitute. As in (1):

1. Several linguists attended the masquerade. They were dressed up as cyclic transformations (De Beaugrande, 1980. p. 146). Here, the pronoun "they" replaces the subject "several linguists."

\subsubsection{Possessive pronouns}

Possessives are of two types: Determiners which are followed by nouns and contain (their, its, her, his, your, my, and our) and pronominals which are not followed by anything and include (theirs, ours, yours, his, hers, and mine). As in (2):

2. Our house is quite different from his.

In this example, the pronoun "his" refers back to and substitutes "our house."

\subsubsection{Demonstrative pronouns}

In English, there are four demonstrative pronouns, namely, this, that, these, those.

3. I hear that you dislike his latest novel. I read his first novel. That was very boring too (Quirk and Greenbaum, 1973. p. 341).

In (3), the demonstrative pronoun "that" is used as substitution to the nominal phrase "his first novel."

\subsubsection{Quantitative pronouns}

Due to the fact that these pronouns show quantity, they are named as quantitative in grammar. These pronouns include some, any, each, both, much, many, all.

4. The boys applied for a scholarship. Each was able to present excellent references (Quirk and Greenbaum, 1973. p. 331). The quantitative pronoun "each "(4) is used to substitute the subject "the boys."

\subsubsection{Unitary quantifier}

The substitute one/ones always function as head of the nominal group and can substitute only for an item which is itself a head of a nominal group.

5. Do you have any knives? I need a sharp one.

Here, in (5) one for "knives" functions as the head of the noun phrase.

\subsection{6. "The same" as substitution}

The substitute "same" is typically accompanied by the unlike one, which presupposes only the noun head, the same presupposes an entire nominal group including any modifying elements. As in (6) bellow:

6. A. I'll have two poached eggs on toast, please.

B. I'll do the same.

The substitute "the same" is used to avoid the repetition of the nominal clause "two poached eggs on toast. 


\subsection{Verbal Substitution}

The verbal substitution in English is "do." It operates as head of a verb phrase, in the place that is occupied by the lexical verb; and its position is always final in the group. For Haliday and Hasan (1976), verbal substitution is associated with contrast or it brings into new information. As shown in 7:

7. He never really succeeded in his ambitions. He might have done, one felt, had it not been for the restlessness of his nature. Here, "done" substitutes for succeeded in his ambitions and serves also to link the two sentences by anaphora, exactly same way as the nominal substitute one.

\subsection{Clausal Substitution}

The words used as substitution are "so and not." There are three environments in which clausal substitution takes place: Report, condition, and modality. In each of these environments, it may take either of two forms, positive or negative; the positive is expressed by so, the negative by not. Magriby (2010).

\subsubsection{Reported clause}

The reported clause that is substituted by so or not is always declarative, whatever the mood of the presupposed clauses. There is no substitution for interrogative or imperative indirect questions or commands, and therefore the clauses substitution do not follow verbs such as wonder, order or ask.

8. "...if you've seen them so often, of course you know what they're like."

"I believe so," Alice replied thoughtfully (Haliday and Hasan, 1976. p. 131).

In (8), "so" substitutes I know what they're like.

\subsubsection{Conditional clause}

Conditional clauses are frequently substituted by "so" and "not," they especially follow if but also in other forms such as assuming so, suppose not:

9. Everyone seems to think he's guilty. If so, no doubt he'll offer to resign.

In (9) "so "that follows the conditional particle refers back to and replaces the whole previous clause "to think he is guilty."

\subsection{Types of Substitution in Bahdini Kurdish}

In Kurdish language three types of substitutions are found namely:

\subsubsection{Nominal substitution}

It consists of substituting a noun with a pronoun. This

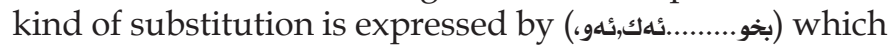
is used to replace either the noun or the noun phrase (Adel, 2012. p. 97). For example:

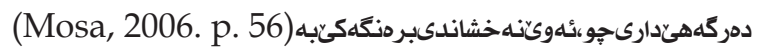

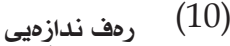

In (10), the pronoun ندوين refers back to the previous

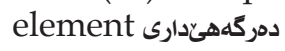

\subsubsection{Verbal substitution}

In this type, the verb is substituted by another verb. The expression is done by the substituted verb بكهم in its form. In other words, a verb comes instead of another verb or a verb phrase. For example;

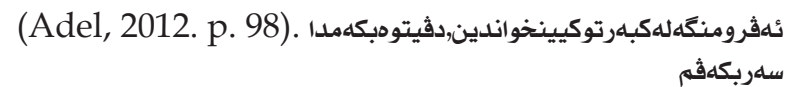

\subsubsection{Clausal substitution}

A language unit is used instead of a sentence or any other grammatical unit on one condition that the substituted unit should contain all the features of substitution. As shown in (12):

$$
\begin{aligned}
& \text { بيدثيهمروفههرددمهاريكارياكهسينهلهزاربكهت،داكوئوزئزيانه كاخوشب }
\end{aligned}
$$

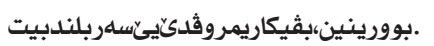

All places of the substitution are entered; the external substitution is rarely used. It is used only in conversation, i.e., it depends on the things that have been mentioned previously. The substitution element comes first (Adel, 2012. p. 98).

\subsection{Data Analysis and Discussion}

In this section, the renderings of all subjects will be analyzed and discussed.

\section{English SL Text}

1. Mike has a new blue bicycle. He bought it yesterday (Azar, 1992. p. 76).

\begin{tabular}{lll}
\hline Type & Presupposing unit & Presupposed unit \\
\hline $\begin{array}{l}\text { Nominal-personal } \\
\text { pronoun }\end{array}$ & He & Mike \\
\hline \hline
\end{tabular}

\section{B.A. Renderings}

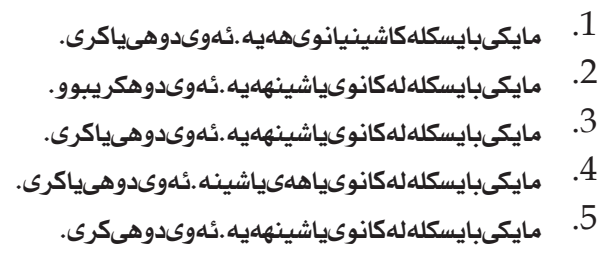

\section{Discussion}

Subjecting the renderings to close scrutiny, one can see that all subjects have supplied the personal pronoun " as equivalent to the substitute "He "وى". This pronoun is a masculine pronoun in Kurdish. The results show that the proper equivalent to "Mike" is "ئدوى" and rendering (5) is the best one due to tense and the concept of the English sentence.

$$
\text { مايكىبايسكله لكانوىياشينياهوى.ندوىدهيكرى. }
$$

2. Our house is quite different from his (Quirk, et al., 1985. p. 890).

\begin{tabular}{lll}
\hline Type & Presupposing unit & Presupposed unit \\
\hline $\begin{array}{l}\text { Nominal-possessive } \\
\text { pronoun }\end{array}$ & His & Our house \\
\hline \hline
\end{tabular}




\section{B.A. Renderings}

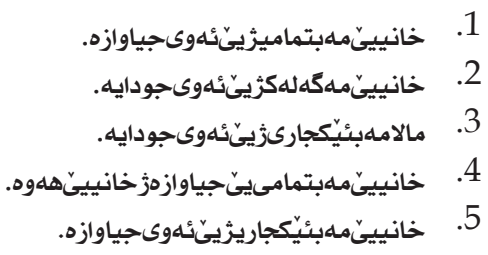

\section{Discussion}

It is clear from the renderings that translators 1,2 , 3 , and 5 have rendered the nominal substitute "our" which replace "مه " in "in " in the previous clause as while translator 4 did not use substitution as he used the word “خانيين".

All subjects have succeeded in rendering the nominal substitution "our." Moreover, this is due to the fact that Bahdini Kurdish has an equivalent to the nominal خانيين substitute "his." Thus, the most accurate rendering is مهبتماميزيئنئهوىجياوازه

I hear that you dislike his latest novel. I read his first novel. That was very boring too (Quirk and Greenbaum, 1973. p. 341).

\begin{tabular}{lll}
\hline Type & Presupposing unit & Presupposed unit \\
\hline $\begin{array}{l}\text { Demonstrative } \\
\text { pronoun }\end{array}$ & That & his first novel \\
\hline \hline
\end{tabular}

\section{B.A. Renderings}

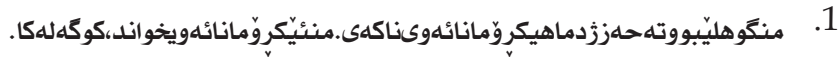

$$
\begin{aligned}
& \text { مانديكهربوو }
\end{aligned}
$$

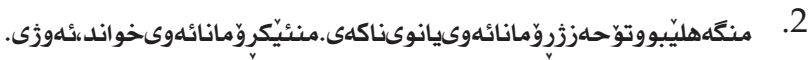

$$
\begin{aligned}
& \text { كَهلهكنهخوَشبوو }
\end{aligned}
$$

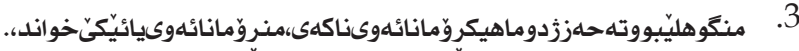

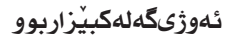

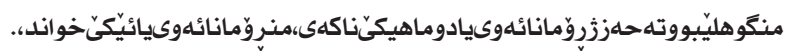

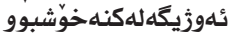

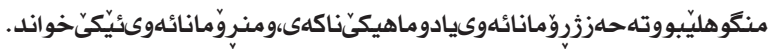

$$
\begin{aligned}
& \text { ئهورييابِّاربوو }
\end{aligned}
$$

\section{Discussion}

Unfortunately, most of the renderings are inappropriate as subjects did not pay attention to the tense of the sentences. Subject one used the feminine marker " 1 " to replace the demonstrative pronoun "that." Subjects 2, 3, 4, and 5 have rendered "that" as which refers to "his first novel." Thus, a proper equivalent to "that" is is and the best rendering is no. 5 .

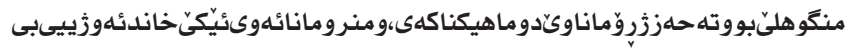
زاربو.

3. The boys applied for a scholarship. Each was able to present excellent references (Quirk and Greenbaum, 1973. p. 331)

\begin{tabular}{lll}
\hline Type of substitution & Presupposing unit & Presupposed unit \\
\hline Quantifier pronoun & Each & The boys \\
\hline \hline
\end{tabular}

\section{B.A. Renderings}

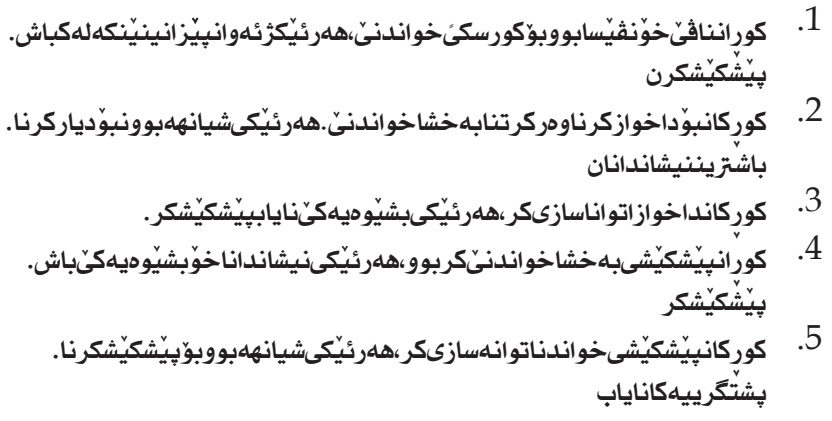

\section{Discussion}

Various equivalents have been supplied by subjects to the هuantifier pronoun substitute "each" which are هلئيكرئهوان by three subjects and هـرئيكئitwo subjects. Accordingly, the best rendering is number 5 .

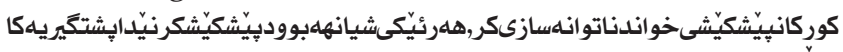
نايابهلهبيت.

4. These biscuits are stale. Get some fresh ones (Quirk, et al., 1985. p. 870).

\begin{tabular}{lll}
\hline Type & Presupposing unit & Presupposed unit \\
\hline Unitary pronoun & Ones & These biscuits \\
\hline \hline
\end{tabular}

\section{B.A. Renderings}

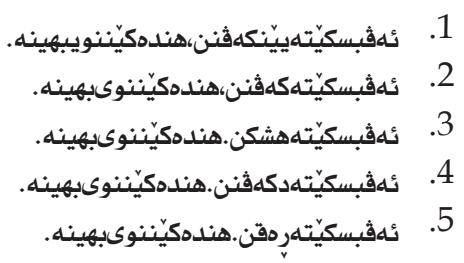

\section{Discussion}

A close inspection of Bahdini Kurdish, for examples $1,2,3,4$, and 5 with their renderings, reveals that all subjects have replaced the linking plural marker in Bahdini Kurdish "هندوكين" as equivalent to substitute the pronoun "ones." Rendering number 4 seems to be more accurate than others. ئهفبسكيّتهدكهفنن.هندوكيّننوىبهينه 5. Happy New Year! Thank you. The same to you (Eastwood, 2000. p. 49).

\begin{tabular}{lll}
\hline Type & Presupposing unit & Presupposed unit \\
\hline Nominal-the same & The same & Happy new year \\
\hline \hline
\end{tabular}

\section{B.A. Renderings}

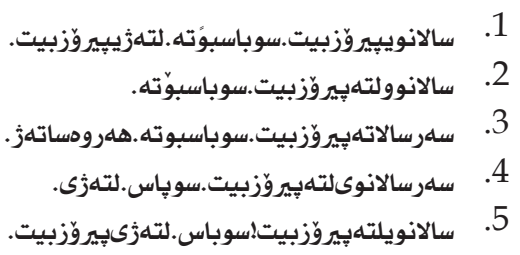

Original article | doi: 10.25007/ajnu.v6n3a72 


\section{Discussion}

All subjects have supplied the same equivalents to the nominal substitute "the same" which is jز. The best rendering is rendering number 2. سالانوولتهبيروزبيت:سوباسبوّته. I"

6. He is going to build a swimming pool. I wish we could do so (Chalker, 1984. p. 266).

\begin{tabular}{lll}
\hline Type & Presupposing unit & Presupposed unit \\
\hline Verbial - do & Do & build a swimming pool \\
\hline \hline
\end{tabular}

\section{B.A. Renderings}

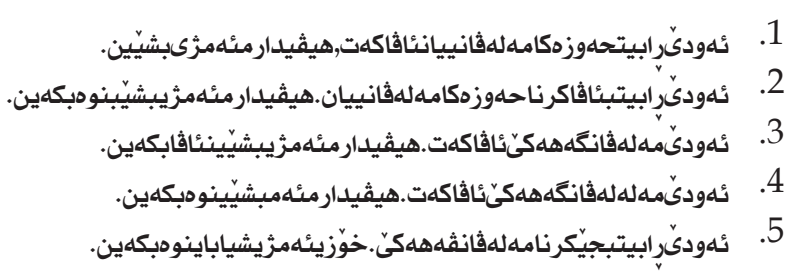

\section{Discussion}

Working through these examples carefully, one soon notices that subjects 1 and 2 have rendered the verbal substitute "do" as دشيّين while subjects 3 and 4 have translated it into بيشين ind it seems the most accurate equivalent. The last subject has rendered the verbal substitute as شياباين. It is worth mentioning that the words شيَين،بشيّين hand شياباين have the same meaning. And thus, the proposed rendering is number 1.

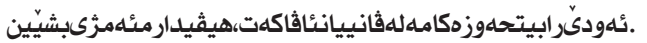

7. I might murder my husband. Oh! 'I wouldn't do that if I were you (Eastwood, 2000. p. 49).

\begin{tabular}{lll}
\hline Type & Presupposing unit & Presupposed unit \\
\hline verbial - do & Do & murder my husband \\
\hline \hline
\end{tabular}

\section{B.A. Renderings}

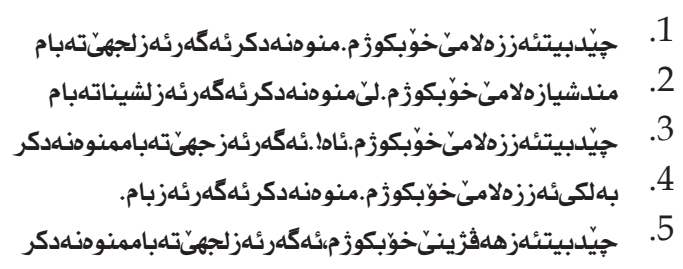

\section{Discussion}

Judging respondents' renderings, one can say that subjects 1,2 , and 4 have rendered the verbal substitute "wouldn't do" as ghile subjects 3 and 5 have rendered the verbal substitution as ومناكهو "do" is ودنهدكر and therefore the best rendering is number 1 .

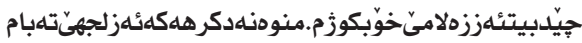

8. Does Jean sing?

- Yes, she does.

- No, but Mary does (Haliday and Hasan, 1976. p. 127).

\begin{tabular}{lll}
\hline Type & Presupposing unit & Presupposed unit \\
\hline Verbal - does & Does & Sing \\
\hline \hline
\end{tabular}

\section{B.A. Renderings}

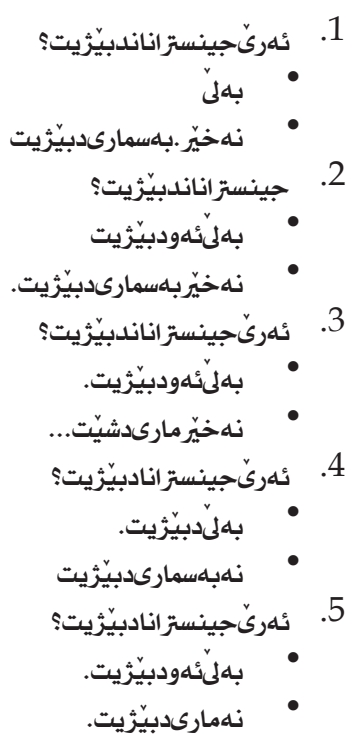

\section{Discussion}

For the first part of the answer, it is clear that the first subject preferred ellipsis to finding an equivalent to the substitute in rendering number 1, while subjects 2, 3, 4, and 5 supplied the word دبيّريت as an equivalent to substitute "sing." As far as the second part of the sentence is concerned, it is clear that all subjects used the word دبيّريت as equivalent to substitute "sing." Rendering number 1 is the best one.

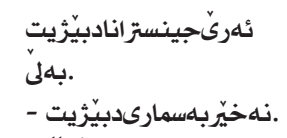

9. "We are going to have a very cold winter" I hope not (Chalke, 1984. p. 268).

\begin{tabular}{lll}
\hline Type & Presupposing unit & Presupposed unit \\
\hline Clausal & not & $\begin{array}{l}\text { We are going to have a very cold } \\
\text { winter }\end{array}$ \\
\hline \hline
\end{tabular}

\section{B.A. Renderings}

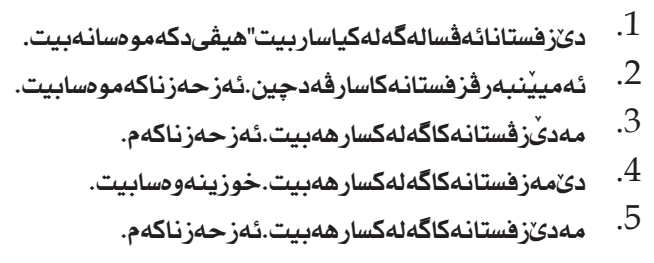

\section{Discussion}

A close look at subjects' renderings reveals that none of the subject has used ellipsis. Subjects have supplied different words such as ودسانهبيت and equivalents to substituted reported clause "not." All subjects have failed to give 
appropriate renderings. Therefore, the accurate rendering will be the following one:

مهدئز ڤستانهكاكهلهكسار هلبيت.نئزحهزناكهم

10. She is expecting twins. How do you know that? (Quirk, et al., 1985. p. 868).

\begin{tabular}{lll}
\hline Type & Presupposing unit & Presupposed unit \\
\hline Clausal & That & That she is expecting twins \\
\hline \hline
\end{tabular}

\section{B.A. Renderings}

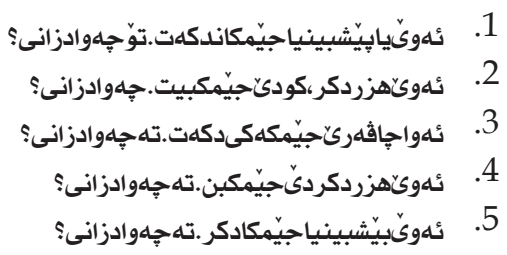

\section{Discussion}

We can notice from the renderings that all subjects have preferred ellipsis to finding an equivalent to all substitutes. Subjects 2, 3, 4, and 5 have negatively rendered the tense into past tense while the tense of the source text is present. The following rendering is the proposed one.

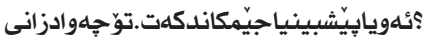

11. It is a lovely weather for ducks. Perhaps so, but I am not a duck (Chalker, 1984. p. 268).

\begin{tabular}{lll}
\hline Type & Presupposing unit & Presupposed unit \\
\hline Clausal & So & It is a lovely weather for ducks \\
\hline \hline
\end{tabular}

\section{B.A. Renderings}

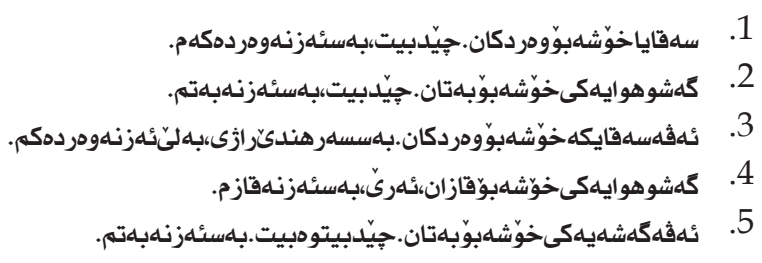

\section{Discussion}

Three subjects, namely $(1,2$, and 4$)$, have preferred ellipsis to finding an equivalent to the substitutes. Whereas subject 5 has supplied the word ودبيت as equivalent to the clausal substitute "so." We can also note that subject 3 has failed to give any rendering to the clausal substitute "so". Accordingly, the best rending is 5 .

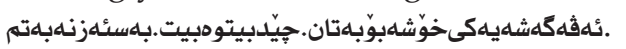

12. Are you going to the conference? If so, we could travel together (Jackson, 1980. p. 97).

\begin{tabular}{lll}
\hline Type & $\begin{array}{l}\text { Presupposing } \\
\text { unit }\end{array}$ & Presupposed unit \\
\hline Conditional clause & So & Are going to the conference \\
\hline \hline
\end{tabular}

\section{B.A. Renderings}

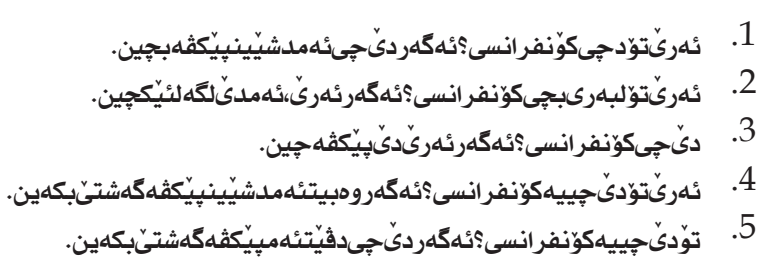

\section{Discussion}

In the renderings of the subjects 1 and 5 , both have preferred to repeat the main verb دئ instead of the presupposed unit "so," and thus we have no substitution. Subjects 2 and 3 have translated the clausal substituted "so" which correlates with the conditional particle "if" as whilst the subject 4 used the word ودبيت as substitution for "so." The appropriate rendering is the last one.

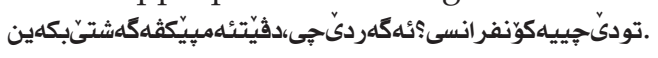

\section{FINDINGS AND DISCUSSIONS}

From the analysis above, this study has come up with the following findings:

1. The percentages of translated substitution units have been as follows:

- Nominal substitution $(82.857 \%)$

- Verbal substitution (93.33\%)

- Clausal substitution (42.5\%).

From the percentages above, we can conclude that the subjects have managed to translate verbal and nominal substitutional units from English into Bahdini Kurdish with high percentages, while in translating clausal substitutional units, the subjects have scored lower percentages compared with verbal and nominal one.

2. It is possible for substitution in the source language to have more than one form in the target language. Moreover, one of the translated forms can be the most appropriate corresponding to the form in the source language.

3. Both phenomena of substitution and ellipsis can be found in Bahdini Kurdish.

4. Bahdini Kurdish uses some markers to replace either the noun or the noun phrase like (نيكوىنبخه.....) as in 1 and 5.

5. It is possible to use ellipsis as a solution where no appropriate equivalent for the substituted word is found as in text number 11.

6. It can be noticed that a substitute in the source text may not appear in the translated target text as in text 12.

7. It can be noted that Bahdini Kurdish has no equivalents for the English possessives pronouns.

\section{CONCLUSION}

This study has come up with the following conclusions:

1. Substitution units are very helpful to indicate the meaning relationships and to interpret units containing 
TABLE 1

Percentages of Substitution Units from English into Bahdini Kurdish

\begin{tabular}{lc}
\hline \hline Types of substitution & Percentage \\
\hline Nominal & \\
Personal pronoun "he" & 100 \\
Possessive pronoun "our house" & 80 \\
Demonstrative pronoun "that" & 100 \\
Quantifier pronoun "each" & 100 \\
Unitary pronoun "ones" & 100 \\
The same & 100 \\
Total ratio & 82.857 \\
Verbal substitution & \\
Auxiliary verb "do" & 100 \\
Auxiliary verb "do" & 100 \\
Auxiliary verb "does" & 80 \\
Total ratio & 93.33 \\
Clausal & 100 \\
Hope not & Zero \\
That & 10 \\
Perhaps so & 60 \\
If so & 42.5 \\
Total ratio & \\
\hline \hline
\end{tabular}

lexical words by showing how the units are related to each other. As shown in Table 1.

2. The linguistic context can be regarded as an important factor that affects the rendering of substitutional units.

3. Bahdini Kurdish like English has three types of substitution which are:

- Nominal substitution

- Verbal substitution

- Clausal substitution

4. When facing a difficulty in finding an appropriate equivalent in rendering substitutional units. Subjects tend to use ellipsis to overcome the difficulty.

5. In many cases, substitutional units may have more than one equivalent to a substitute in the target language.

6. It can be noticed, in both Bahdini Kurdish and English, usually function words replace (substitute) lexical words, i.e. that, pronouns usually replace nouns or noun phrases except for verbal substitution, a lexical verb substitutes another lexical verb.

\section{REFERENCES}

Adel, A.S. (2012). Linguistics of Text. Analysis of some Kurdish texts as Examples. Unpublished MA Thesis. Douhuk University.

Azar, B.S. (1992). Fundamentals of English Grammar. New York: Longman. Bloomfield, L. (1933). Language. London: George Allen and Unwin Ltd.

Chalker, R. (1984). Current English Grammar. London: McMillan Publisher Ltd.

Conlin, D.A. (1961). Grammar for Written English. Boston: Houghton Mifflin Company.

De Beaugrande, R. (1980). Text, Discourse and Process Towards a Multidisciplinary Science of Texts. London: Longman.

Eastwood, S. (2000). Oxford Guide to English Grammar. Oxford: Oxford University Press.

Haliday, M.A.K \& Hasan, R. (1976). Cohesion in English. London: Longman. Jackson, H. (1980). Analyzing English: An Introduction to Descriptive Linguistics. London: Pergamon Press Ltd.

Kelin, E. (1967). A Comprehensive Etymological Dictionary of the English Language. Vol. 2. Amsterdam: Elsevier Publishing Company.

Magriby, P. (2010). Substitution: A Grammatical Cohesion. Available from: http://www.gosrok.blogspot.com/2012/02/substitutiongrammatical-cohesion.html. [Last accessed on 2017 Jun 01].

Mosa, T.S. (2006). Mouths Do Not Say Any Thing. Dahuk: Hawar Publishing Office.

Newmark, P. (1982). Approaches to Translation. London: Pergamon Press Ltd.

Parrott, M. (2000). Grammar for English language Teachers. Cambridge: Cambridge University Press.

Querol, M. (2012). Substitution as a Device of Grammatical Cohesion in English Narrative and its Translation into Spanish.

Quirk, R \& Greenbaum, S. (1973). A University Grammar of English. London: Longman.

Quirk, R. (1968). The Use of English. London: Longman.

Quirk, R., Greenbaum, S., Leech, G \& Svartvik, J. (1985). A Comprehensive Grammar of the English Language. London: Longman Group Ltd.

Thi, H.N. (2011). A Contrastive Study of Grammatical Cohesive Devise in English and Vietnamese. Ho Chi Minh: University of Education.

Whitehall, H. (1956). Structural Essentials of English. London: Longman.

Yeh, C. (2004). The relationship of cohesion and coherence: A contrastive study of English and Chinese. Journal of Language and Linguistics, 3, 130-156. 